\title{
RESEARCH COMPILATION: QUATERNARY SEDIMENTS
}

Research on Recent and Pleistocene Sedimentary Deposits in the Atlantic Provinces and Adjacent Areas: Current and Recently Completed Work.

\author{
BRENDA P. LAMING \\ Fredericton, N.B.
}

This compilation deals with current research activity on Quaternary sedimentary deposits, both Recent and Pleistocene, in the Atlantic Region, listing all work, of any kind, that has been reported to the editors of Maritime Sediments. The Atlantic Region is defined, for the purposes of this compilation, as the Atlantic Provinces of Canada, adjacent land areas, and marine areas from Cape Cod to the Eastern Canadian Arctic and from the St. Lawrence estuary to the Mid-Atlantic Ridge.

Most of the information has been obtained in response to questionnaires answered during September and October, 1966. Other items, marked with an asterisk (*) in the main 1 ist, are those for which no questionnaire was returned: information for these was derived from previous issues of Maritime Sediments, and a few are from the G.S.C. Report of Activities, May to October, 1965 (Geological Survey of Canada Paper 66-1, ed. S E. JENNESS, 1966); these items are therefore less up-to-date.

For each project, the main 1 ist shows the names of research worker(s), institutions(s) and status of research; the classified 1 ist indexes key topics. Where news or a report of the work has appeared in Maritime Sediments previously, reference is made on the right-hand side (citation of volume, number and page); if from the G.S.C.Report of Activities, page reference $(66-1 \mathrm{pm})$ is made instead. Institutions of those responding to questionnaires are listed on pages 204-205.

Status of research, as reported by the questionnaire respondent, is indicated by letters at the left margin:

$\begin{array}{ll}\text { rs } & \text { recent1y started } \\ \text { a } & \text { active } \\ \text { nc } & \text { nearly complete } \\ \text { rc } & \text { recent1y completed } \\ \text { s } & \text { suspended, will be completed later } \\ * & \text { no questionnaire returned. }\end{array}$

ABBOTT, D. N.B.R.P.C., \& T. HERBERT Michigan Composition of moraines in areas of subsurface mineralization, Bathurst, $N$. B. nc Investigation of heavy mineral content and rock debris in glacial deposits as a guide to mineralisation.

AII, S.I. Intertidal gravel bodies, Chignecto Bay: see LAMING 
ALLEN, R.C. Be11 Telephone

2 -ii 111

* Surface properties of continental shelf sediments, southwest Nfld.

ANDERSON, T.W. Water 100

rs Palynology of postglacial deposits in Prince Edward Island.

ANDREWS, J.T. \& G. FALCONER Geog. Branch Isostatic recovery and changes in marine fauna in !1) Foxe Basin-

a. involving a study of the nature of isostatic recovery and direction of tilting; 2) Ekalugad Fiord to Cape Hooper (Baffin Island) a study

of the effects of local deglacierization pattern in isostatic recovery;

3) Ottawa Islands (Hudson Bay) a study since deglacierization.

ANTHONY, E.H. Foraminiferal ecology, Arctic: see VILKS

ANTHONY, E.H. Foraminifera, Bras d'Or Lake: see VILKS

AYER, N。 Gulf of Maine: see RICHARDS

BARGHOORN, E. Fresh water peat, continental shelf: see EMERY

BARNETT, D.M. Geog. Branch

Sublacustrine morphology of a proglacial lake. Generator Lake, central

a. Baffin Island, N.W.T. Depths sounded through lake ice, profiles established close to ice-cliffs (part of Barnes Ice Cap), to discover presence or absence of cross-valley moraines. Preliminary plots show occurrences of ridges in the lake.

BARR, S.M. Recent sediments, Cardigan Bay: see LAMING

BARTLETT, G.A. B.I.O. 2-ii 86

* Ecological studies of foraminifera in Atlantic Provinces waters.

BEALS, H. Dalhousie 2-ii 70

* Manganese-iron concretions in Nova Scotia lakes.

BEALS, $H$. Kelvin Seamount and Bermuda Pedestal: see STANLEY

BELDING, H.F. Esso $\quad 2-i$ i 112

* Sediment and deep hole testing on the Atlantic seaboard.

BOND, G.C. Suspended matter, coastal waters: see MANHEIM

BORNS, $H$. Bay of Fundy: see SWIFT

BOWER, M.E. Aeromagnetic surveys: see HOOD

BUTTNER, P.J. Rochester

Response models of shoreline complexes. Beach, along-shore bar,

a and lagoon study in selected shoreline areas to develop models (analytical and simulation) for comparison of Middle and Upper

Devonian of New York with present day. Field and computer work.

BYERS, D. Debert, periglacia1 eolian deposits: see SWIFT

CHASE, R.I. W.H.O.I. Sedimentary rocks dredged from the Mid-Atlantic Ridge at $42^{\circ} 40^{\prime} \mathrm{N}$

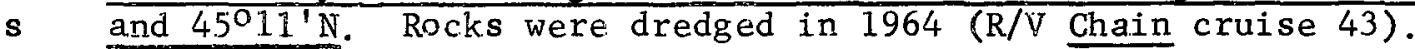
Samples have been sent to Rith Todd. (U.S.G.S.) and T. Saito (Lamont).

COOKE, H.B.S. Fresh water peat, continental shelf: see EMERY 
CRAIG, B.C. G.S.C. Quaternary geology of Hudson Bay Lowland. One phase of a large scale rs ail inclusive reconnaissance to be undertaken by the Survey in 1967. Almost all of this area was submerged following deglaciation so history of marine deposition and 1 and emergence caused by isostatic readjustment is significant in the study.

DAVIES, T. Sable Island Bank: see STANLEY

DRAPEAU, G. Dalhousie, \& D.J. STANLEY Smithsonian 1-iv 2, 2-ii 85 Terraces and the Holocene Transgression on the Nova Scotian Shelf.

nc Details the location and depth of terraces between the Northeast Channe1 and the Laurentian Channe1; Holocene still-stands of sea level demonstrated; sub-bottom profiling and sediment analysis.

EMERY, K.O., J _C. HATHAWAY, J HÜLSEMAN, F。T. MANHEIM, P.F. MCFARLIN, A.S. MERRIIL, R。M. PRATT, D.A.ROSS, J.SCHLEE, J.V.A.TRUMBULL, \& E. UCHUPI W.H.O.I.; T.G.GIBSON, J.E. HAZEL \& M. RUBIN U.S.G.S.; D.J. STANLEY Smithsonian; C. SCHELSKE \& R.L. WIGLEY Com. Fish * W.H.O.I.-U.S.G.S. program for the Atlantic Continental Margin 2-ii 55

EMERY, K.O. W.H.O.I.; R.I. WIGLEY COM. Fish; M. RUBIN U.S.G.S.; E. BARGHOORN Harvard; H.B.S. COOKE Dalhousie Fresh water peat on the continental shelf. About 10 samples containing

nc fresh water peats have been obtained from the shelf off New England at depths as great as 80 metres. Their presence serves as added information of lowered sea level during the past 12,000 years (see a.1so EMERY, Atlantic Continental Margin)

EMERY, K.O. W.H.O.I.; F.C. WHITMORE Jr. U.S.G.S; \& D.J.P. SWIFT Puerto Rico nc Elephants on the continental shelf. 30 teeth of mastodons and mammoths have been dredged from the continental shelf off New England; their presence supplements other findings related to low sea levels during the past 15,000 years. The range of variation of tooth measurements is much less than for similar collections from land, a result of the relatively short time span $(20,000$ to 10,000 years $)$ represented by the samples (see also EMERY, Atlantic Continental Margin).

ESTES, A. Pollen studies, N.S. lakes: see LIVINGSTONE

FALOONER, $G$. Isostatic recovery, Arctic: see ANDREWS

FEYLING-HANSSEN, R.W. Aarhus

Stratigraphy and fossil content of the Cape Christian cliffs, east

a. central Baffin Island (in association with O.H. LQKEN).

FROTHINGHAM, J.R. Jr. Atlantic Continental Margin sediments: see SCHLEE

GADD, N.R。 G.S.C.

* Surficial geology in the St. Sylvestre area, Quebéc

$(66-1$ p 163)

GIBSON, T.G. Atlantic Continental Margin: see EMERY

GIESE, G.S。 W.H.O.I. Beach pebble movements and shape sorting: indices of swash zone mechanics 
GRANT, A.C. B.I.O.

1) Continuous seismic profiles on the continental shelf of NE Labrador,

rc using CSS Hudson, July 1965.

2) Continuous seismic profiling, Hudson Bay, using CSS Hudson,

nc July-Sept. 1965

$2-i \overline{31,2}-i i \quad 87$

3) Continuous seismic profiling in Ungava Bay and Hudson Strait,

is using CCGS Labrador, August 1966.

GRANT, A.C。\& J.M. STEWART B.I.O.

Continuous seismic profiling, NE Newfoundland continental margin,

a using $\mathrm{M} / \mathrm{V}$ Theta, June-Ju1y 1966 .

GRANT, D.R. Cornel1

1) Drift Dispersion, N.S. Study of lithological frequency analysis

rc of tilis between Yarmouth and Canso are related to source areas and ice currents.

2) Superposed Red Drumlin Ti11, N.S. Study of drumlin-forming

rc fine grained red till in coastal districts; characteristic lithologies of individual drumlin fields.

3) "Transported" Geochemical Anomalies, N.S. Positive anomalies of

rc heavy metals in stream sediments along the Atlantic coast, relationship to red till and to the mineralized Horton-Windsor contact.

4) Ice-Rafting, Scotian Shelf. Interpretation of bottom sediments

rc outside the Cabot Strait in relation to decay of spring drift ice, and probable sources of material in the Gulf of St. Lawrence.

5) Laurentian Channel Sediments. Study of surficial sediments and

nc episodes of erosion, transport and deposition utilising heavy minerals, grain size and microfauna.

HATHAWAY, J.C。\& P。F。MCFARLIN W.H。O.I. Mineralogy of continental margin sediments, N.S. to N.J. (see also

nc EMERY, Atlantic Continental Margin)

HAZEL, J.E. Atlantic Continental Margin: see EMERY

HERBERT, T. Moraines and mineralization, Bathurst, N.B.: see ABBOTT

HICKOX, C.F. Colby Coll. 2-ii 76

* Claciail drainage channels crossing Annapolis County, N.S.

HOOD, P.J., M.E. BOWER, \& P.SAWATZKY G.S.C. 2-i 15, 2-ii 81 Aeromagnetic surveys of the continental shelves and deep ocean: Hudson a Bay, Lrabrador Sea, Scotia Shelf, Grand Banks \& Flemish Cap.

HOOPER, K。 Carleton U $1-i 6$ Holocene Foraminifera and sediments of Eastern Canada, including the

nc continental shelf.

HULSEMANN, J。W.H.O.I。 Organic constituents of sediments of the Atlantic continental margin,

a N.S. to F'lorida. (see also EMERY, Atlantic Continental Margin)

IMPERIAI OII ITD. Core-hole drilling, Grand Banks and Gulf of St.

* Lawrence: see PAN-AMERICAN 
JAMES, N. PanAm \& D.J. STANLEY Smithsonian 1-iv 2, 2-ii 85 Sediment dispersal patterns on (1) Sable Island and (2) Sable Island Bank

rc Distribution of sand-size material on the outer margin of the Scotian Shelf. Origin of sediment; sediment transport by wind, wave, tidal and bottom currents.

JAMES, N. Gully submarine canyon: see STANLEY

JONES, J.F. \& P.C. TRESCOTT N.S. Mines 1-iv $25 \&$ in this issue Surficial and groundwater geology, Annapolis and Cornwallis

nc Va.1leys, N.S.

JUDD, J. Gully submarine canyon: see STANLEY

KING, C.A.M. Pebble characteristics, Baffin Is,: see PHILPOT

KING, L.H. B.I.O. 2-ii 86

* Sediment distribution map of the Scotian shelf from echograms and bottom sampling; tracing of submarine benches; laboratory separation of organic constituents.

KLEIN, G.deV. Pennsylvania \& Hudson Labs 2-i 19, 2-ii 110 Relation of directional properties of intertidal zone sediments to flow

a directions and flow velocity of tidal currents, Five Islands and Economy Point, Minas Basin shore, N.S. The purpose is to relate direction properties (bedforms, grain orientation) and variation in texture and mineralogy to changes of flow of tidal currents. Also a. study to relate flow parameters (depth, velocity, sediment textures) to bedform scale. Bouys moored at low tide are visited during periods of submergence to monitor changes in flow direction and parameters. Sediments are sampled for textural and mineralogical analysis; box cores taken of sedimentary structures, and peels made using epoxy and hardener.

KRANCK, K.M. B.I.O. 2-ii 86

* Petrological studies of sediment and bedrock of Northumberland Strait.

KRANCK, K.M. B.I.O., \& MARINE SCIENCE CENTRE, MCGill 2-ii 86

* Co-operative project in Belle Isle Strait.

KRAUSE, D.C. Rhode Island 2-ii 87

* Seismic profiling of New England Continental Margin.

KRINSLEY, D. Debert, periglacial eolian deposits: see SWIFT

LAI, J. Gulf of Maine: see RICHARDS

LAMING, D.J.C. U.N.B.; S.I. ALI G.S. Pakistan; \& N. SZABO U.N.B. Intertidal and subtidal gravel bodies in Chignecto Bay, 2-i 3, 2-iii 134

a Bay of Fundy. Study of gravel bodies in Alma and Salisbury Bays and near Cape Enragé, south shore of New Brunswick; detailed sampling and aerial photography over a period of years, continuous seismic profiling; study of texture and composition of gravels in relation to nearby glacio-fluvial deposits, buried channels and late Pleistocene events.

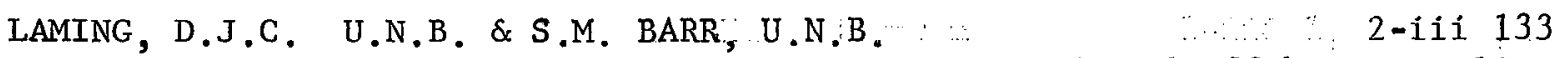
Recent sediments in Cardigan Bay, P.E.I. Beach and offshore sampling

a in a large natura1 harbour undertaken in summer 1966 ; textural and carbon analyses to be related to computed wave effects. 
LAMING, D.J.C. U.N.B. \& J.W. ROWLING Chevron 1-iii 1, 2-i 32, Recent sediments and morphology of bars, channels and 2-iii 133

a islands, Rustico Harbour, P.E.I. Sampling and detailed surveys in several successive years during which marked changes in channel and island morphology have been observed. Textural analyses to relate grain size to movements of sand bodies; observation of island-building processes.

LANGILLE, J. Pleistocene geol, of N.S.: see MacNEILI

LAUZIER, L.M. F.R.B.

Residual bottom drift over the Continental Shelf, Canadian Atlantic

a. coast. Bottom currents as shown by sea-bed drifters afe related to sedimentation. Observations are made from the Gulf of St. Lawrence to Gulf of Maine and Bay of Fundy. Observations began in 1961 and are continued.

LEE, H.A. G.S.C.

* The Grand Falls morainic system, N.B.

$(66-1$ p 168)

LIVINGSTONE, D., A. ESTES \& M. STEWART Duke Pollen studies of Nova Scotia lakes - interglacial, late-glacial and

a post-glacial deposits from Eastern Canada (mostly lacustrine from Nova Scotia)

LøKEN, O.H. Geog. Branch Geomorphology and Pleistocene chronology of east central Baffin Island

a. 1) glacial landforms and raised shore features 2) submarine geomorphology of the fiords and adjacent parts of the continenta1 terrace 3) till fabric and pebble characteristics of drift deposits

LORING, D.H., \& C.J.G. NOTA B.I.O. Geomorphology, sedimentology and geochemistry of the Gulf of St. Lawrence

a Begun in 1961, 1) depositional condition in the river and gulf, 2) geomorphology and sedimentology of the southern gulf (Magdalen Shallows); detailed mineralogy and geochemistry of sediments

LYALL, A. Bay of Fundy: see SWIFT

MCDONALD, B.G. G.S.C. $(66-1$ p 167) Pleistocene geology studies, Richmond-Sherbrooke region, SE Québec.

McDONALD, V.J. Gulf of Maine: see RICHARDS

MCFARLIN, P.F. Mineralogy continental margin: see HATHAWAY.

MCMASTER, R.L. Rhode Island 2-ii 111

* Sediments of the shelf, sounds, bays and beaches in Narragansett Bay, Rhode Island Sound, Block Island Sound and between Georges Bank and Hudson Canyon.

MCMULLEN, R.M. B.I.O.

2-iii 131

1) Bottom sediments of the Grand Banks, Newfoundland surface sediment

a. samples, grain-size distribution, heavy and light minerals, pebble and clay mineral analysis to establish provenance and sedimentological history.

2) Bottom sediments from the Hecla and Gripes Bay area, Queen Elizabeth

rs. Islands, N.W.T.

2-ii 87

McMULLEN, R.M. Bay of Fundy: see SWIFT 
MacNEILL, R.H. Acadia \& N.S.R.F. $1-\mathrm{i} i \mathrm{i} 16$

* Variation in content of some drumlins and tills in SW N.S.

Ma.cNEILI, R.H., E. MacQUARRIE, K. PHILLIPS \& J. LANGILLE N.S.R.F. Pleistocene Geology of Nova Scotia - active work for 16 years; pre-

nc liminary surficial mapping on mainland areas expected to be complete in 1968 .

MacQUARRIE, E. Pleistocene geo1 of N.S.: see MacNEILL

MANHEIM, F.T., R.H. MEADE, J.V.A. TRUMBULL, G.C. BOND, \& E. UCHUPI W.H.O.I. a Suspended matter in Atlantic and Gulf coastal surface waters (see also EMERY, Atlantic Continental Margin)

MARINE SCIENCE CENTRE, MCGill Belle Isle Strait: see KRANCK

MARLOWE, J.I. B.I.O. 2-ii 87

* Mineralogical aspects of Baffin Bay sediments and their relationship to ancient currents

MEADE, R.H. Suspended matter, coastal waters: see MANHEIM

MEDIOLI, F. Halifax Harbour, N.S.: see STANLEY

MEDIOLI, F。 Kelvin Seamount and Bermuda Pedestal: see STANLEY

MEDIOLI, F. Sable Island Bank: see STANLEY

MERRILL, A.S. Atlantic Continental Margin: see EMERY

MILLER, J. Dalhousie 2-ii 84

* Suspended sediment transport in the Bay of Fundy.

MOORE, M.C. Gulf of Maine: see RICHARDS

MOTT, R.J. G.S.C. Palynology of postglacial and late Pleistocene deposits in Cape

rc Breton Island.

NOTA, D.J.G. Guif of St. Lawrence: see LORING

O'BRIEN, N.R. N.Y.S.U. Dia.toms in the Leda Clay (Pleistocene), St. Lawrence River Valley,

a near Massena, N.Y. Electron microscope investigation indicates presence of nannofossil diatoms, size ranges less than 1 micron to 6 microns in diameter; paleoecological significance of the diatoms is also under study.

OLSON, R. Gu1f of Maine: see RICHARDS

PAN-AMERICAN PETROLEUM CORP. \& IMPERIAL OIL LTD. $2-i 34$

* Core hole drilling, Grand Banks \& Gulf of St. Lawrence.

PAUL, R. Shallow structure, continental margin: see UCHUPI

$\begin{array}{lr}\text { PELLETIER, B.R. B.I.O. } & \text { 2-ii } 87\end{array}$ Bottom topography and sediments of Polar Continental Shelf between

a. Ellef Ringnes and Borden Islands, Franklin District, N.W.T. Physica1 and geochemical properties of bottom sediments related to environment and physical framework of the depositional site. 
PELLETIER, B.R. \& F.J.E. WAGNER, B.I.O. Bottom studies in Jones Sound, Franklin District, N.W.T. Submarine

a topography and fauna.

PELLETIER, B.R., F.J.E. WAGNER, \& A.C. GRANT B.I.O. 2 -i 30 Marine geological studies in Hudson Bay, Keewatin District, N.W.T.

a. Submarine topography, sediments and fauna and sub-bottom studies of geological structures and formations.

PHILLIPS, K. Pleistocene geol. of N.S.: see MacNEILL

PHILPOT, J.T. Geog. Branch \& C.A.M. KING Nottingham

Comparative study of pebble characteristics in Ekalugad Fiord,

a Baffin Island, N.W.T.

PHIPPS, C. Sydney 1 1-iii 35

* Sedimentological \& geochemical study of sediments on Continental Shelf E. of Halifax.

PHIPPS, D. McGil1

Equilibrium between sodium and clay minerals in the marine environment

rs Lab experiments will be performed in artificial sea water to determine the rates of attainment of equilibrium; recent marine clays will also be analysed.

PICKETT, T.E. Kelvin Seamount and Bermuda Pedestal: see STANLEY

PISKIN, R. Gulf of Maine: see RICHARDS

PLEISTOCENE GEOLOGY SECTION G.S.C. 1-iv 21

* New Glacial Map of Canada, one of a series for issue in Centennial

Year, and concurrently a new account of Surficial Deposits and Pleistocene History for inclusion in 5th Ed. of Geol. \& Econ. Minerals of Canada.

PRADA, K. Shallow structure, continental margin: see UCHUPI

PRATT, R.M. Atlantic Continental Margin sediments: see SCHLEE

RICHARDS, A.F., R. OLSON, N. AYER, R. PISKIN, J . LAI, V.J . MCDONALD, M.C. MOORE IIlinois

Mass physical and engineering properties of Wilkinson Basin sediments,

a Gulf of Maine. Laboratory study of 1arge-diameter cores and measurement in place on sea-floor of shear strength (vane shear probe) bulk density (gamma-ray transmission probe) and pore pressure (piezometer probe).

ROSS, D.A. Atlantic Continental Margin: see EMERY

ROWLING, J.W. Recent sediments, Rustico Harbour: see LAMING

RUBIN, M. Fresh water peat, continental shelf: see EMERY

SANDERS, J.E. Hudson Labs 2-i 23

* Geological Calibration Attempt of Side-Looking Sonar, Minas Basin, N.S.

SAWATZKY, P. Aeromagnetic surveys: see HOOD

SCHELSKE, P. Atlantic Continental Margin: see EMERY 
SCHLEE, J.S., J.R. FROTHINGHAM Jr., R.M. PRATT W.H.O.I. Texture of the Atlantic Continental Margin sediments, grain size of

nc bottom sediment samples collected on a 10-mile grid over she1f and slope. (see also EMERY, Atlantic Continental Margin)

SCHWARTZ, M. Brook1yn Col1. 1-iv 11 Beach observations along $E$ coast of N.S. to determine patterns of

a tidal-cycle sedimentation in the littoral zone. Indian Harbour and Smith Cove, Guysborough Co. chosen because of minimal shore-drift characteristics. Fluoresecent tracers were injected in depth and samples taken in sequence along the beach profile.

SHEARER, J. Memorial Recent sediment distribution in Port-au-Port Bay, Newfoundland.

a Mineralogy and texture of the bottom sediments to be compared with mineralogy and texture of the beach and Pleistocene deposits with the hope of establishing a source; also weathering and erosive processes undergone by sediments to be studied.

SILVERBERG, N. Sable Island Bank: see STANLEY

STANLEY, D.J. Smithsonian 2-iii 135

* Color of sediments on the Atlantic continental margin (see also EMERY, Atlantic Continental Margin)

STANLEY, D.J. Smithsonian 2-iii 134

* Statistical analysis of coastal sand deposits (see also BUTTNER)

STANLEY, D.J. et al Smithsonian

Submarine geology of the Nova Scotian continental shelf and slope. A

a long term project concerned with origin and distribution of sediments, bottom and sub-bottom morphology; ice-rafting, submarine canyon sedimentation, reconstruction of the Holocene transgression and sedimentary dispersal patterns.

STANLEY, D.J. Smithsonian; T. DAVIES S. Carolina; F. MEDIOLI Dalhousie; N. SILVERBERG Washington; \& D.J.P. SWIFT Puerto Rico 1-iv 2, Sedimentation on the continental slope and rise off Sable 2-ii 85

nc Island Bank, N.S. Texture, mineralogy and faunal content of the modern deep-sea sediments. Origin of materials; sediment transport downslope.

STANLEY, D.J. Smithsonian; N. JAMES PanAm; \& J. JUDD Rutgers 1-iv 2, Modern and Quaternary sediment transport via the Gully $\quad 2-i i \quad 86$

rc submarine canyon:

1) the sediment types found and how materials move downslope; 2) how source and supply has been affected during the glacial periods, during the Holocene transgression and in recent time. Evidence of turbidite and non-turbidite movement.

STANLEY, D.J. Smithsonian \& D.J.P. SWIFT Puerto Rico Concretions on Georges Bank. Origin, distribution, petrography

nc and contained fossils.

STANLEY, D.J. Smithsonian, \& F. MEDIOLI Dalhousie 2-ii 86, 2-iii 134

* Sediment and foraminiferal dispersal patterns in the Northwest Arm, Halifax Harbour, N.S. 
STANLEY, D.J., T.E. PICKETT Smithsonian; D.J.P. SWIFT Puerto Rico; F. MEDIOLI, H. BEALS Dalhousie 2-ii 85 Morphology and sediment distribution of Kelvin Seamount chain $\left(39^{\circ} \mathrm{N}\right.$

* and $\left.64^{\circ} \mathrm{W}\right)$, the Bermuda Pedesta.1 and Apron, and the Bermuda Is lands.

STANLEY, D.J. Sable Island: see JAMES

STANLEY, D.J. Terraces, N.S. Shelf: see DRAPEAU

STEWART, J.M. Seismic profiles, NE Nf1d.: see GRANT

STEWART, M. Pollen studies, N.S. lakes: see LIVINGSTONE

SWIFT, D.J.P. Puerto Rico; R.M. McMULLEN B.I.O.; A. LYALL Dalhousie; $\&$ H. BORNS Maine 2-ii 84 and in this issue

1) Qua.ternary sedimentation and stratigraphy in the Bay of Fundy and

a 2) Geometry and primary structures of tide-maintained sand bodies, eastern Bay of Fundy.

SWIFT, D.J.P. Puerto Rico; D. BYERS Phillips; \& D. KRINSLEY Queens Coll

* Periglacial eolian deposits at the Debert archaeological $2-i 25$ site, N.S.

SWIFT, D.J.P. Elephants, continental shelf: see EMERY

SWIFT, D.J.P. Concretions, Georges Bank: see STANLEY

SWIFT, D.J.P. Kelvin Seamount and Bermuda Pedestal: see STANLEY

SWIFT, D.J.P. : Sable Island Bank: see STANLEY

SZABO, N. Intertidal gravel bodies, Chignecto Bay: see LAMING

TAGG, R. Shallow structure, continental margin: see UCHUPI

TERASMAE, J. G.S.C.

1-ii 19

1) Palynology of postglacial deposits in Riviére-du-Loup, Québec, to

nc Fredericton, N.B.

2) Palynological and paleobotanical study of samples of submerged peat

a near Sable Island.

TIPHANE, M. Montrea1

$1-i$ i 5

Texture, mineralogy and origin of surface sediments in the Gulf of St.

a. Lawrence, Québec. Mud samples taken of Chaleur Bay and between Gaspé and Anticosti Island, also shore sands and gravels of the Gaspe Peninsula.

TRESCOTT, P.C. Surficial geol, parts N.S.: see JONES

TRUMBULL, J.V.A. Suspended matter, coastal waters: see MANHEIM

UCHUPI, E., R. TAGG, R. PAUL, K. PRADA W.H.O.I. 2-iii 117 Shaliow structure of the continental margin from N.S. to Florida Keys

nc seismic profiles, about $16,000 \mathrm{~km}$ have been recorded; the 10,500 joule sparker used has given penetrations of $0.5-1 \mathrm{~km}$. This structural section probably represents the entire Tertiary. Throughout this time the continental slope in the area appears to have been formed by sediment progradation seaward. This deltaic structure was modified during the Pleistocene by cutting of canyons along the slope (see also EMERY, Atlantic Continental Margin)

UCHUPI, E. Suspended matter, coastal waters: see MANHEIM 
VILKS, G。 B.I.O.

rs Foraminifera of the Hecla and Gripes Bays and Hazen Strait, N.W.T.

VILKS, G. \& E。D.ANTHONY B.I.O. Distribution studies of foraminifera in Bras d'Or Lake, Cape Breton

nc Island Variance and mean of population counts was used to study the micro-distribution of benthic Foraminifera. Analysis of variance applied to study of temporal and lateral changes in counts. Association analysis used to study ecological discontinuities in the area.

VILKS, G。, E。 H. ANTHONY, \& $W_{0} T$ 。 WILLIAMS B。I.O. Application of association analysis to a survey of the sediment fauna

rc of an Arctic Basin. The use of a statistical model in the studies of foraminiferal ecology was tested.

WAGNER, F.J.E. B.I.O. $2-i i \quad 86$

* Fossils of the ancient Champlain Sea.

WAGNER, F.J.E. Jones Sound, N.W.T.: see PELLETIER

WAGNER, F.J.E. Marine geology, Hudson Bay: see PELLETIER

WHITMORE, F.C. Jr. Elephants, continental shelf: see EMERY

WIGLEY, R.L. Fresh water peat, continental shelf: see EMERY

WILLIAMS, W.T. Foraminiferal ecology, Arctic: see VILKS

YORATH, C. Queen's

1-iii 35

* Sedimentological, foraminiferal \& ecological study of scotian Shelf, E. of Halifax.

ZEIGLER, J. W.H.O.I.

$2-i$ i 111

* Coastal dynamics, velocity profile in the zone of shoaling waves, genesis of coastal currents and mechanics of ripple motions.

\section{GEOGRAPHICAI INDEX}

Key words from all items in the main 1 ist are indexed here according to area and main field of study. Geographical division of the continental shelf gives six marine areas, plus another for deep sea work. Land locations are listed under the adjacent marine area.

\section{GULF OF MAINE \\ including Cape Cod and Georges Bank areas.}

\section{Recent Sediments}

Atlantic Continenta1 Margin program: EMERY et al

Beach pebble movements \& shape sorting: GIESE
Block I Sound, sediments: McMASTER

Bottom currents \& sedimentation, Gulf of Maine: LAUZIER

Coastal currents: ZIEGLER

Coastal dynamics: ZIEGLER

Coastal sand deposits, statistical analysis: STANLEY 
Colour of sediments, Continental margin: STANLEY

Concretions, Georges Bank: STANLEY \& SWIFT

Continental margin, colour of sediments: STANLEY

Continental Margin, mineralogy of sediments : HATHAWAY \& McFARIIN

Continental margin, texture of sediments: SCHLEE et al

Continental margin, shallow structure: UCHUPI et al

Georges Bank, concretions: STANLEY $\&$ SWIFT

Georges Bank to Hudson Canyon, sediments: McMASTER

Gu1f of Maine, bottom currents \& sedimentation: LAUZIER

Hudson Canyon to Georges Bank, sediments: McMASTER

Mineralogy, Continental Margin sediments: HATHAWAY \& McFARLIN

Narragansett Bay, sediments : McMASTER

Peat on shelf: EMERY et al

Response models, shoreline complexes: BUTTNER

Rhode I Sound, sediments: McMASTER

Ripple motions, coastal: ZIEGLER

Sea leve1 changes, peat on shelf: EMERY et al

Shallow structure, continent margin: UCHUPI et al

Shape sorting \& beach pebble movements : GIESE

Shoreline complexes, response models: BUTTNER
Statistical analysis, coastal sand deposits: STANLEY

Suspended matter in coastal surface waters: MANHEIM et al

Swash zone mechanics: GIESE

Texture of sediments, Continenta1 Margin: SCHLEE et al

Wave motions, coasta1: ZIEGLER

$\underline{\text { Pleistocene Geology }}$

Atlantic Continental Margin program: EMERY et al

\section{Paleontology}

Atlantic Continental Margin program: EMERY et al

Elephants on shelf: EMERY et a1

\section{Other}

Atlantic Continental Margin, organic constituents : HULSEMAN

Engineering properties, Wilkinson Basin sediments, Gulf of Maine: RICHARDS et al

Mineralogy, Continental Margin sediments: HATHAWAY \& McFARLIN

New England continental margin, seismic profiling: KRAUSE

Organic constituents, Atlantic Continental Margin: HULLSEMAN

Seismic profiling, New England continental margin: KRAUSE

Wilkinson Basin sediments, Gulf of Maine; engineèring $\&$ phýsical properties: RICHARDS et al

BAY OF FUNDY

\section{Recent Sediments}

Annapolis Valley, NS, groundwater geology: JONES \& TRESCOTT

Bay of Fundy, sediments: SWIFT et al

Bottom currents \& sedimentation, Bay of Fundy: LAUZIER

Chignecto Bay, gravel bodies: LAMING \& SZABO

Cornwall is Valley, NS, groundwater geology: JONES \& TRESCOTT

Economy Point, intertidal zone sediments : KLEIN

Five Islands, intertidal zone sediments: KLEIN
Gravel bodies, Chignecto Bay: LAMING \& SZABO

Intertidal gravels, Chignecto Bay: LAMING \& SZABO

Intertidal zone sediments, Five Islands, Economy Point, Minas Basin shore: KLEIN

Minas Basin shore, intertidal zone sediments : KLEIN

Suspended sediment transport in Bay of Fundy: MILLER

Tidal currents \& intertidal zone sediments, Five Islands, Economy Point \& Minas Basin: KLEIN 
Tide-maintained sand bodies, E Bay of Fundy: SWIFT et a1

Transport of suspended sediment in Bay of Fundy: MILLER

\section{$\underline{\text { Pleistocene Geology }}$}

Annapolis Co, NS, glacial drainage channels: HICKOX

Annapolis Valley, NS, surficial geology: JONES \& TRESCOTT

Bay of Fundy, sedimentation \& stratigraphy: SWIFT et al

Cornwallis Valley, NS, surficial geology: JONES \& TRESCOTT
Debert, periglacial eolian deposits: SWIFT et al

Eo1ian periglacial deposits, Debert: SWIFT et a1

Glacial drainage channels, Annapolis Co, NS : HICKOX

Nova Scotia, Pleistocene geology: MCNEILL et al

\section{Other}

Groundwater geology, Annapolis \& Cornwallis valleys: JONES \& TRESCOTT Sonar, side-1ooking, calibration, Minas Basin: SANDERS

\section{SCOTIAN SHELF}

\section{Recent Sediments}

Bottom currents \& sedimentation, Scotian Shelf: LAUZIER

Continental shelf $\mathrm{E}$ of Halifax, sedimentology: PHIPPS C.

Continental shelf, E of Halifax, sedimentology: YORATH

Continental shelf \& slope, submarine geology: STANLEY et al

Dispersal patterns of sediments, Sable I \& Sable I bank: JAMES \& STANLEY

Distribution of sediments, Scotian Shelf: KING L.H.

Eastern shore NS, 1ittora1 zone: SCHWARTZ

Gully submarine canyon, sediment transport: STANLEY et a1

Hal ifax Harbour, sediment dispersal: STANLEY \& MEDIOLI

Holocene Transgression, Scotian Shelf: DRAPEAU \& STANLEY

Littoral zone, tidal-cycle sedimentation, E shore NS: SCHWARTZ

Organic constituents in Scotian. shelf sediment: KING L.H.

Sable I \& Sable I Bank, sediment dispersal patterns: JAMES \& STANLEY

Scotian Shelf, bottom currents $\&$ sedimentation: LAUZIER

Scotian Shelf, sediment distribution map : KING L.H.

Submarine geology, continental shelf \& slope: STANLEY et al

Tidal-cycle sedimentation, littoral zone, E shore NS: SCHWARTZ

\section{Pleistocene Geology}

Drift dispersion, NS: GRANT D.R. Druml in till, NS: GRANT DoR.

Drumlins \& tills, SW N S, variation in content: MacNEILL

Gully submarine canyon, sediment transport: STANLEY et al

Ice-rafting, Scotian shelf: GRANT D.R.

Nova Scotia, Pleistocene geology: MacNEILL et al

Terraces, Scotian Shelf: DRAPEAU $\&$ STANLEY

Till, red drumlin, NS: GRANT D.R.

Tills \& drumlins, SW N S, variation in content: MacNEILL

\section{Paleontology}

Bras d'Or L, Cape Breton, foraminifera distribution: VILKS \& ANTHONY Cape Breton, Brak d'Or L, foraminifera distribution: VILKS \& ANTHONY

Cape Breton, palynology of postglacial \& 1ate Pleistocene: MOTT

Continental shelf, E of Halifax, foraminifera \& ecology: YORATH

Ecology, foraminifera, Atlantic Provinces waters: BARTLETT

Foraminifera, Atlantic Province waters: BARTLETT

Foraminifera distribution, Bras d'Or L, Cape Breton: VILKS \& ANTHONY

Foraminifera \& ecology, continental shelf E of Halifax: YORATH

Halifax Harbour, foraminiferal dispersal: STANLEY \& Medioli 
Lakes in NS, palynology:

LIVINGSTONE et al

Palynology, NS Lakes: LIVINGSTONE et a1

Palynology of postglacial \& late Pleistocene, Cape Breton I: MOTT

Palynology of submerged peat, Sable I: TERASMAE

Peat, submerged near Sable I, palynology: TERASMAE

Sable I, palynology of submerged peat: TERASMAE

Other

Aeromagnetic survey, Scotian Shelf: HOOD et al
Concretions, N. S, lakes: BEALS

Continental shelf $\mathrm{E}$ of Halifax, geochemistry of sediments: PHIPPS $C$.

Geochemistry of sediments, continental shelf $\mathrm{E}$ of Halifax: PHIPPS $C$.

Geochemical stream anomalies, NS: GRANT D.R.

Manganese-iron concretions, NS lakes: BEALS

Scotian Shelf, aeromagnetic survey: HOOD et al

Stream sediments, geochemical anomalies, NS: GRANT D.R.

GULF OF ST. LAWRENCE

including St. Lawrence River Valley, Cabot Strait, and west coast of Newfoundland

\section{Recent Sediments}

Anticosti I - Gaspé bottom sediments study: TIPHANE

Beach mineralogy \& texture, Port-auPort Bay: SHEARER

Belle Isle Strait: KRANCK \& McGILL

Bóttom currents \& sedimentation, Gulf of St. Lawrence: LAUZIER

Cardigan Bay, P E I, sediments: LAMING \& BARR

Chaleur Bay, sedimentology: TIPHANE

Core hole drilling, Gulf of St. Lawrence: PAN-AMERICAN \& IMPERIAL

Fredericton, N.B, to Riviere-du-Loup Qué, palynology, postglacial deposits: TERASMAE

Gaspé-Anticosti I, bottom sediments study: TIPHANE

Gulf of St. Lawrence, bottom currents \& sedimentation: LAUZIER

Gulf of St. Lawrence, core hole drilling: PAN-AMERICAN \& IMPERIAL

Gulf of St. Lawrence, mineralogy $\&$ geochemistry of sediments: LORING \& NOTA

Island morphology, Rustico Harbour, $\mathrm{P} \cdot \mathrm{E}$ I: LAMING \& ROWLING

Laurentian Channel sediments: GRANT D.R.

Mineralogy of sediments, Gulf of St. Lawrence: LORING \& NOTA

Mineralogy \& texture of sediments, Port-au-Port Bay: SHEARER
Northumberland Strait, petrology of sediments: KRANCK

Port-au-Port Bay, mineralogy \& texture of sediments: SHEARER

Post glacial deposits, P E I, palynology: ANDERSON

Rivière-du-Loup, Qué. tỏ Fredericton N B, palynology, postglacial deposits: TERASMAE

Rustico Harbour, P E I, sediments: LAMING \& ROWLING

Surface properties, continental shelf sediments, SW Nf1d: ALLEN

SW Nfld continental shelf sediments, surface properties: ALLEN

\section{P1eistocene Geology}

Bathurst, N B, moraines, heavy minerals: ABBOTT \& HERBERT

Champlain Sea, fossils: WAGNER Grand Falls, N B, moraines: LEE Moraines, Grand Falls, N B: LEE Moraines, heavy minerals, Bathurst N B: ABBOTT \& HERBERT

Pleistocene deposits, Port-au-Port Bay: SHEARER

Richmond-Sherbrooke region, Qué, Pleistocene geology: McDONALD B.G. Sherbrooke-Richmond region, Qué, Pleistocene geology: McDONALD B.G. St. Sylvestre area, Qué, surficial geology: GADD 


\section{Paleontology}

Diatoms, Leda $\mathrm{Clay}$, St. Lawrence $\mathrm{R}$ valley, N Y: O'BRIEN

Ecology, foraminifera, Atlantic Provinces waters: BARTLETT

Foraminifera, Atlantic Provinces waters: BARTLETT

Laurentian Channel microfauna: GRANT D.R.

Leda Clay, St. Lawrence $R$ valley $N \mathrm{Y}$, diatoms: O'BRIEN

Palynology, postglacial deposits, P E I: ANDERSON
Palynology, Riviere-du-Loup, Qué to Fredericton N B: TERASMAE

St. Lawrence $R$ valley, diatoms in Leda Clay, Massena, $N$ Y: O'BRIEN

Other

Geochemistry, Gulf of St. Lawrence: LORING \& NOTA

Geomorphology, Gulf of St. Lawrence: LORING \& NOTA

Gulf of St. Lawrence, geomorphology, \& geochemistry: LORING \& NOTA

\section{N.E. NEWFOUNDLAND, LABRADOR SHELF AND GRAND BANKS}

\section{Recent Sediments}

Core hole drilling, Grand Banks: PANAMERICAN \& IMPERIAL

Grand Banks, core-hole drilling: PANAMERICAN \& IMPERIAL

Mineralogy of sediments, Grand Banks: MCMULLEN

Grand Banks, bottom sediments: MCMULLEN

\section{Other}

Aeromagnetic survey, Grand Banks, Flemish Cap \& Labrador Sea: HOOD et a1
Continental shelf, NE Nfld, seismic profiling: GRANT A.C. \& STEWART

F1emish Cap, aeromagnetic survey: HOOD et al

Grand Banks, aeromagnetic survey: HOOD et a1

Labrador Sea, aeromagnetic survey: HOOD et al

Labrador shelf NE, seismic profiles: GRANT A.C.

Nfld NE, continental shelf, seismic profiling: GRANT A.C. \& STEWART

Seîsmic profiles, NE Labrador she1f: GRANT A.C.

Seismic profiling, NE Nfld continental margin: GRANT A.C. \& STEWART

\section{EASTERN ARCTIC}

including Hudson Bay

\section{Recent Sediments}

Baffin I, Ekalugad Fiord, pebble characteristics: PHILPOT \& KING

Baffin Bay sediments, mineralogy $\delta$ relation to ancient currents: MARLOWE

Bottom topography, Jones Sound, N W T PELLETIER \& WAGNER

Bottom topography \& sediments, Polar continental shelf, Ellef Ringnes I to Borden I, N W T: PELLETIER

Ekalugad Fiord, Baffin I, pebble characteristics: PHILPOT \& KING

Ellef Ringnes $I$ to Borden I, N W T Polar continental shelf: PELLETIER
Gripes Bay, Qu. E1izabeth Is, N W T, bottom sediments: McMULLEN

Hecla Bay, Qu. E1izabeth Is, N W T, bottom sediments: McMULLEN

Hudson Bay, submarine topography \& sediments: PELLETIER et al

Jones Sound, N W T, bottom topography: PELLETIER \& WAGNER

Mineralogy of Baffin Bay sediments: MARLOWE

Pebble characteristics, Ekalugad Fiord, Baffin I: PHILPOT \& KING

Polar continental shelf, E1lef Ringnes I- to Börden, I, N W:T: PELLETIER 
Sub-bottom studies, Hudson Bay: PELLETIER et a1

Submarine topography, Hudson Bay: PELLETIER et al

\section{Pleistocene Geology}

Baffin I, Cape Christian cliffs, Pleistocene chronology: FEYLINGHANSSEN

Baffin I, geomorphology, pleistocene chronology, raised beaches, fiord \& shelf morphology, till fabrics: L $\emptyset \mathrm{KEN}$

Baffin I, isostatic recovery: ANDREWS \& FALCONER

Baffin I, sublacustrine morphology, Generator L: BARNETT

Cape Christian, Baffin I, P1eistocene chronology: FEYLING-HANSSEN

Continental shelf morphology, E central Baffin I: LøKEN

Deglacierization, Baffin I \& Hudson Bay: ANDREWS \& FALCONER

Foxe Basin, isostatic recovery: ANDREWS \& FALCONER

Fiords, Baffin I: LØKEN

Generator $L$, Baffin $I$, moraines in 1 ake: BARNETT

Geomorphology, Baffin I: LøKEN

Hudson Bay Lowland, isostatic readjustment $\&$ marine deposition: CRAIG

Isostatic readjustment, Hudson Bay Lowland: CRAIG

Isostatic recovery, Foxe Basin, Baffin I, Hudson Bay: ANDREWS \& FALCONER

Jones Sound, N W T, bottom topography: PELLETIER \& WAGNER

Marine deposition, Hudson Bay Lowl and: CRAIG

Moraines, Generator L. Baffin I: BARNETT

Ottawa Is, isostatic recovery: ANDREWS \& FALCONER
Pleistocene chronology, Baffin I: L $\emptyset$ KEN

Proglacial lake, Generator L, Baffin I: BARNETT

Raised beaches, Baffin I: L $\emptyset \mathrm{KEN}$

Til1 fabrics, Baffin I: L $\emptyset \mathrm{KEN}$

\section{Paleontology}

Baffin I, Cape Christian cliffs, fossils \& stratigraphy: FEYLINGHANSSEN

Foraminifera, Hecla \& Gripes Bays \& Hazen Strait, N W T: VILKS

Foraminiferal ecology, statistical model in arctic basin: VILKS et al

Gripes Bay, N W T, foraminifera: VILKS

Hazen Strait, NW T, foraminifera: VILKS

Hecla Bay, N W T, foraminifera: VILKS

Hudson Bay, fauna: PELLETIER et a1 Marine faunal changes, Foxe Basin, Baffin I, Hudson Bay: ANDREWS \& FALCONER

\section{Other}

Aeromagnetic survey, Hudson Bay: HOOD et a1

Hudson Bay, aeromagnetic survey: HOOD et al

Hudson Bay, seismic profiling: GRANT A。C.

Hudson Strait \& Ungava Bay, seismic profiling: GRANT A.C.

Seismic profiling, Hudson Bay: GRANT A.C.

Seismic profiling, Ungava Bay \& Hudson Strait: GRANT A.C.

Ungava Bay \& Hudson Strait, seismic profiling: GRANT A.C.

\section{DEEP SEA}

from the continental slope to the Mid-Atlantic Ridge

\section{Recent Sediments}

Bermuda Pedestal \& Apron and the Bermuda Is, morphology \& sediment distribution: STANLEY et al
Continental slope and rise $S$ of Sable I Bank: STANLEY et al

Kelvin Seamount chain, morphology \& sediment distribution: STANLEY et al 
Faleontology

Continental slope and rise $S$ of

Sable I Bank, faunal content: STANLEY et al
Other

Mid-Atlantic Ridge, sedimentary rocks : CHASE

Sedimentary rocks dredged from MidAtlantic Ridge: CHASE

\section{GENERAL STUDIES IN THE REGION}

\section{Recent Sediments}

Atlantic seaboard, deep-hole tests: BELDING

Holocene foraminifera \& sediments

E. Canada: HOOPER

\section{Pleistocene Geology}

Atlantic seaboard, deep-hole tests: BELDING

Glacial Map of Canada, new: PLEISTOCENE GEOL. SECTION G.S.C. $\underline{\text { Paleontology }}$

Foraminifera, Holocene, E. Canada: HOOPER

Other

Clay minerals \& sodium equilibrium in marine environment: PHIPPS $\mathrm{D}$. Sonar, side-looking, calibration: SANDERS

\section{Late addition to general 1 ist}

MALLICK, K.A. McGilI Weathering of rocks and mobility of elements in soil profiles of

nc Mont St. Hilaire, Que. 1) relative effect of mechanical and chemical transportation of overburden under varying drainage and topographic conditions and on different rock types. 2) correspondence between bedrock and soil composition

\section{LIST OF RESPONDENTS' INSTITUTIONS}

Aarhus

Acadia

B. I. O.

Brook1yn Col1.

Carleton

Chevron

Cornel1

Com. Fish.

Dalhousie

Duke

Geog. Branch
AARHUS UNIVERSITY, Denmark: Feyling-Hanssen. ACADIA UNIVERSITY, Wolfville, N.S.: MacNei11. BEDFORD INSTITUTE OF OCEANOGRAPHY, Dartmouth, N.S.: Anthony, Bartlett, A.C. Grant, L.H. King, Kranck, Loring, McMullen, Marlowe, Pelletier, J M. Stewart, Vilks, Wagner, Williams.

BROOKLYN COLLEGE, Brook1yn, N Y.: Schwartz. CARLETON UNIVERSITY, Ottawa, Ont: Hooper. CHEVRON STANDARD LIMITED, Calgary, Alberta: Rowling CORNELL UNIVERS ITY, I thaca, N.Y.: D.R. Grant. BUREAU OF COMMERCIAL FISHERIES, Woods Hole, Mass.:

Schelske, Wigley. DALHOUSIE UNIVERSITY, Halifax, N S.: Beals, Cooke, Medioli. DUKE UNIVERSITY, Durham, N. Carolina: Estes, Livingstone

M. Stewart.

GEOGRAPHICAL BRANCH, DEPARTMENT OF ENERGY, MINES \& RESOURCES, Ottawa, Ont: Andrews, Barnett, Falconer, Løken, Philpot. 


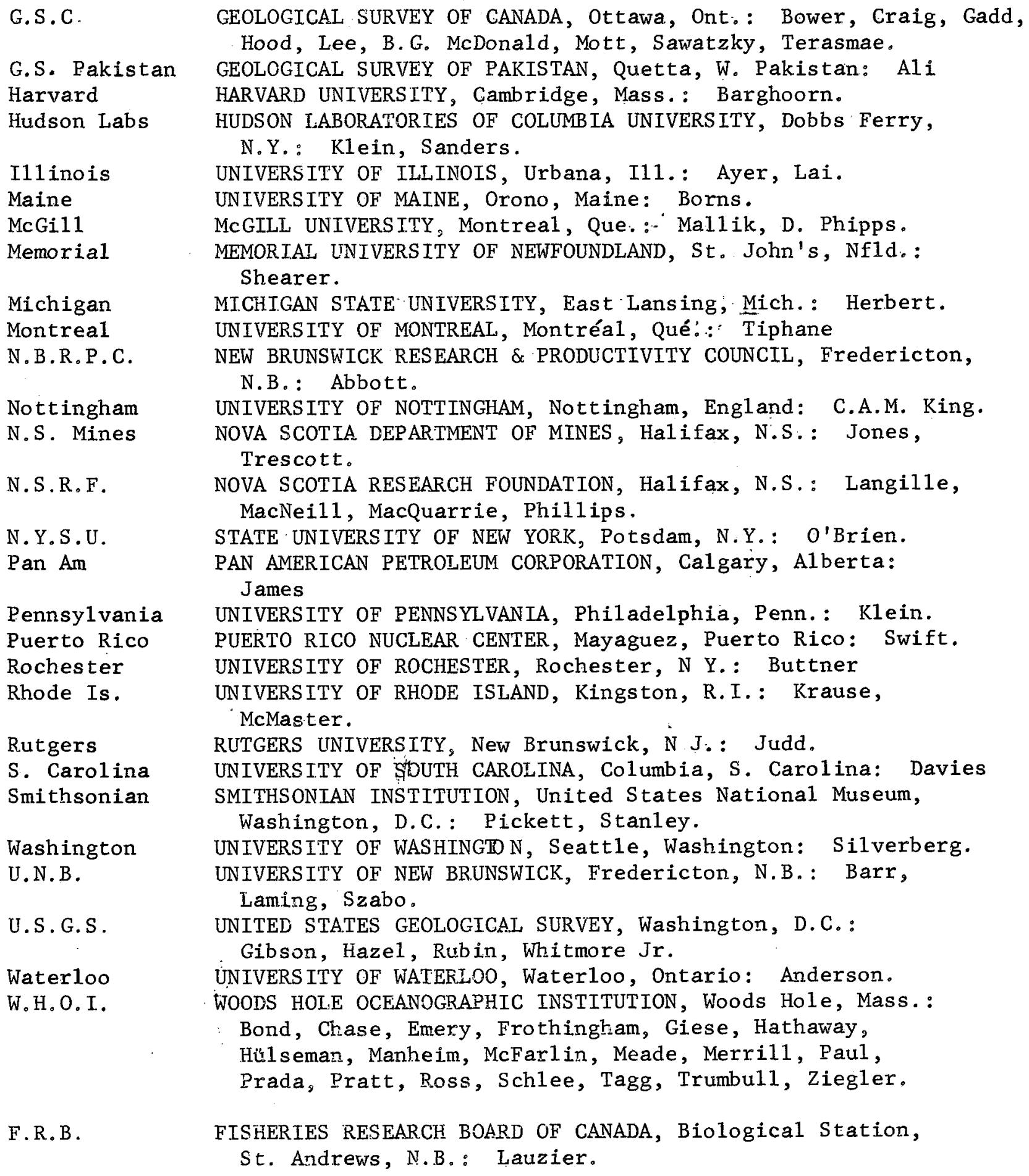


ADDENDUM

Several questionnaires were returned for projects outside the compilation area, and are listed below as an addendum. They are not included in the classified index or index of institutions.

KRAFT, J.C. University of Delaware

a Geology of the sediments and microfauna of the coastal environments of Delaware

MANHEIM, F.T. W.H.O.I. Interstitial waters and chemical composition of JOIDES cores

nc Joint Oceanographic Institutions Deep Earth Sampling drillings off Florida, 1965.

MANHEIM, F.T., R.M. PRATT \& P.F. McFARLIN W.H.O.I. Composition and mineralogy of manganese and phosphate deposits of

a Blake P1ateau.

PILKEY, O.H., P.M. TERLECKY, L.J. DOYLE, E.L. ESTES \& W.C. CLEARY Duke University, Beaufort, N.C. 1-iv 11 Carbonate sedimentation on the Atlantic continental shelf of the

a SE U.S. Aspects of the carbonate fraction under study include size distribution, mineralogy, roundness, organic and inorganic components, ratios of old to fresh shells, broken to whole shells, abundance of black she11s, etc.

SCHUBEL, J.R. Johns Hopkins University, Baltimore, Md. Suspended sediment in Upper Chesapeake Bay. The load, mineralogical

a composition and size distribution are being determined as well as the relative contributions to the total load from various sources.

ANNOUNCEMENT

UNIVERS ITY OF NEW BRUNSWICK

Staff Vacancies in the Department of Geology

Appointments are to be made to the teaching staff of the Department of Geology, commencing in Fall 1967. The present staff consists of seven permanent and two visiting professors. Preference will be given to applications from persons qualified in the following fields:

$$
\begin{aligned}
& \text { Geophysics } \\
& \text { Geochemistry } \\
& \text { Stratigraphy }
\end{aligned}
$$

Persons applying should give details of qualifications, current research activity, publications, and the names of three referees. Applications should be sent to the Chairman, Department of Geology, University of New Brunswick, Fredericton, N.B., Canada, preferably before 1st February, 1967. 